\title{
Postremediation Dose Assessment for the Elza Gate Site, Oak Ridge, Tennessee
}

by M. Nimrnagadda and C. Yu

Environmental Assessment and Information Sciences Division, Argonne National Laboratory, 9700 South Cass Avenue, Argonne, llinois 60439

March 1993

Work sponsored by United States Department of Energy,

Oak Ridge Operations Office, Technical Services Division, Oak Ridge, Tennessee 


\section{CONTENTS}

NOTATION $\ldots \ldots \ldots \ldots \ldots \ldots \ldots \ldots \ldots \ldots \ldots \ldots \ldots \ldots \ldots \ldots \ldots$

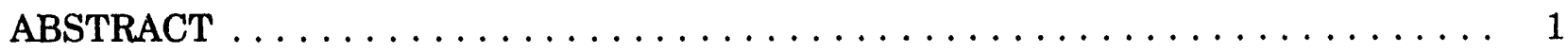

1 INTRODUCTION AND HISTORY $\ldots \ldots \ldots \ldots \ldots \ldots \ldots \ldots \ldots$

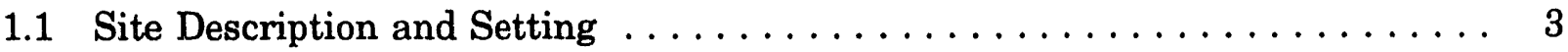

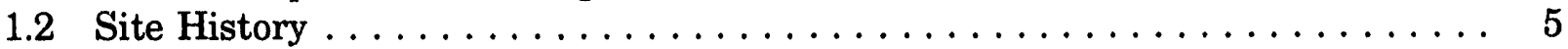

1.3 Summary of Remedial Action Activities $\ldots \ldots \ldots \ldots \ldots \ldots \ldots \ldots$

2 SCENARIO DEFINITIONS $\ldots \ldots \ldots \ldots \ldots \ldots \ldots \ldots \ldots \ldots$

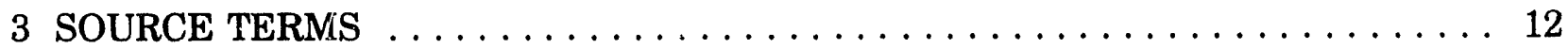

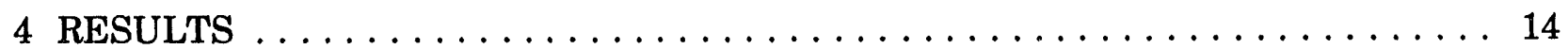

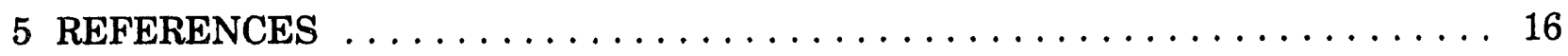

APPENDIX: Parameters Used in the Analysis of the Elza Gate Site . . . . . . . 18

FIGURES

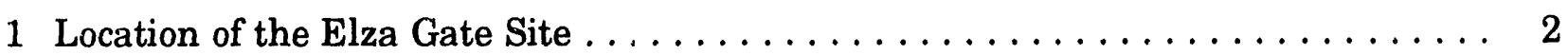

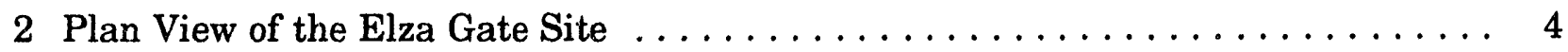

3 Excavated Areas at Parcel $1 \mathrm{~A} \ldots \ldots \ldots \ldots \ldots \ldots \ldots \ldots \ldots$

4 Remediated Areas of Radioactive Contamination $\ldots \ldots \ldots \ldots \ldots$

\section{TABLES}

1 Summary of Pathways for Scenarios A, B, C, and D at the Elza Gate Site

2 Radionuclide Concentrations Used in the RESRAD Code for Analysis of the Elza Gate Site . . . . . . . . . . . . . . . . 13

3 Summary of Potential Maximum Dose Rates for Scenarios A, B, C, and D at the Elza Gate Site . . . . . . . . . . . . . . 14

A.1 Parameters Used in the RESRAD Code for Analysis of the Elza Gate Site 


\section{NOTATION}

The following is a list of acronyms, initialisms, and abbreviations (including units of measure) used in this document.

\section{ACRONYMS, INITIALISMS, AND ABBREVIATIONS}

$\begin{array}{ll}\text { AEC } & \text { U.S. Atomic Energy Commission } \\ \text { BNI } & \text { Bechtel National, Inc. } \\ \text { DOE } & \text { U.S. Department of Energy } \\ \text { FUSRAP } & \text { Formerly Utilized Sites Remedial Action Program } \\ \text { MED } & \text { Manhattan Engineer District } \\ \text { MSL } & \text { mean sea level } \\ \text { ORAU } & \text { Oak Ridge Associated Universities } \\ \text { ORNL } & \text { Oak Ridge National Laboratory } \\ \text { PCB } & \text { polychlorinated biphenyl }\end{array}$

\section{UNITS OF MEASURE}

$\begin{array}{ll}\mathrm{cm}^{2} & \text { centimeter(s) } \\ \mathrm{cm}^{2} & \text { square centimeter(s) } \\ \mathrm{cm}^{3} & \text { cubic centimeter(s) } \\ \mathrm{d} & \text { day(s) } \\ \mathrm{dpm} & \text { disintegrations per minute } \\ \mathrm{ft} & \text { foot }(\text { feet) } \\ \mathrm{g} & \text { gram(s) } \\ \mathrm{h} & \text { hour(s) } \\ \mathrm{ha} & \text { hectare(s) } \\ \mathrm{in} . & \text { inch(es) } \\ \mathrm{kg} & \text { kilogram(s) } \\ \mathrm{km} & \text { kilometer(s) } \\ \mathrm{L} & \text { liter(s) } \\ \mathrm{m} & \text { meter(s) } \\ \mathrm{m} & \text { square meter(s) } \\ \mathrm{m} & \text { cubic meter(s) } \\ \mathrm{mi} & \text { mile(s) } \\ \mathrm{mrem} & \text { millirem(s) } \\ \mathrm{pCi} & \text { picocurie(s) } \\ \mathrm{s} & \text { second(s) } \\ \mathrm{yd} & \text { cubic yard(s) } \\ \mathrm{yr} & \text { year(s) }\end{array}$




\title{
POSTREMEDIATION DOSE ASSESSMENT FOR THE ELZA GATE SITE, OAK RIDGE, TENNESSEE
}

by

\author{
M. Nimmagadda and C. Yu
}

\begin{abstract}
Potential maximum radiation dose rates were calculated for the Elza Gate site in Oak Ridge, Tennessee. The RESKAD computer code, which implements the methodology described in the U.S. Department of Energy's manual for implementing residual radioactive material guidelines, was used in this evaluation. Currently, the site is not being used. Four pctential future use scenarios were considered for the Elza Gate site; the scenarios vary with regard to time spent at the site, sources of water used, and sources of food consumed. In Scenario A (the expected scenario), industrial use of the site is assumed; in Scenario B (a plausible scenario), recreational use of the site is assumed. Both Scenarios $\mathbf{C}$ and D (possible but unlikely scenarios) assume the presence of a resident farmer in the immediate vicinity of the site. The difference between Scenarios C and D is the source of water used. For Scenario $\mathbf{C}$, an adjacent pond provides $100 \%$ of the water for drinking, irrigation, and raising livestock; for Scenario D, groundwater drawn from a well located at the downgradient edge of the contaminated zone is the only source of water for drinking, irrigation, and raising livestock. The results of the evaluation indicate that the U.S. Department of Energy dose limit of $100 \mathrm{mrem} / \mathrm{yr}$ would not be exceeded for any scenario. The potential maximum dose rates for Scenarios A, B, C, and D are $1.5,0.66,12$, and $42 \mathrm{mrem} / \mathrm{yr}$, respectively.
\end{abstract}

\section{INTRODUCTION AND HISTORY}

The Elza Gate site in Oak Ridge, Tennessee, is part of the Formerly Utilized Sites Remedial Action Program (FUSRAP), a U.S. Department of Energy (DOE) program for decontaminating or otherwise controlling sites where residual radioactive materials remain from the early years of the nation's atomic energy program or from commercial operations causing conditions that Congress has authorized DOE to remedy. Elza Gate is a FUSRAP site not owned by DOE.

The Elza Gate site is located in Oak Ridge, Tennessee (Figure 1). Remedial action was conducted at the site in 1991 and 1992. Postremedial action surveys and soil samples 


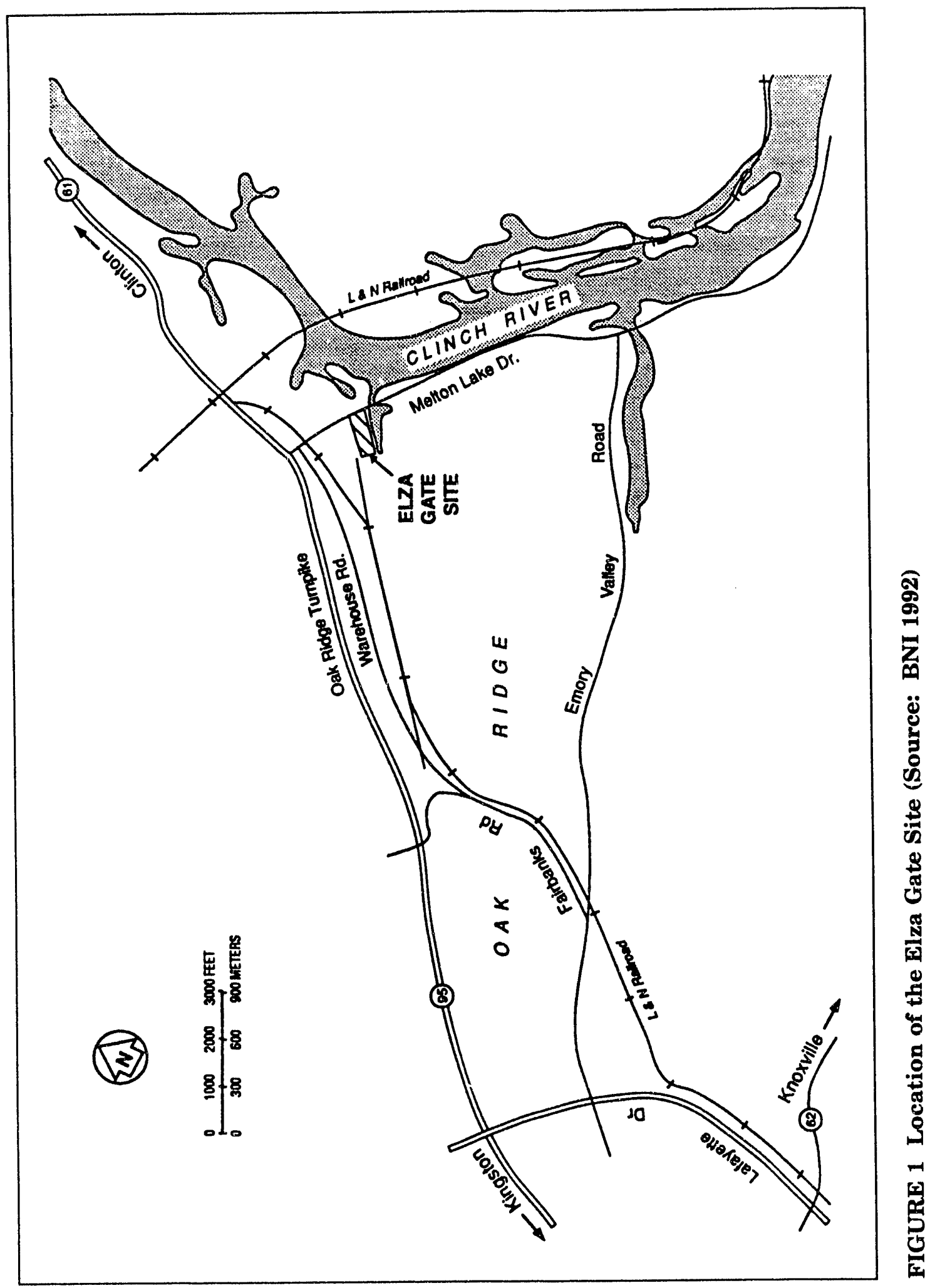


confirm that no radioactivity exceeding DOE guidelines remains in the remediated areas (Bechtel National, Inc. [BNI] 1992). In addition, an independent verification survey confirmed that the site was adequately characterized to identify the types and areal extent of contaminants and that remedial actions were effective in reducing contamination to levels below the DOE guidelines and authorized limits (Vitkus and Bright 1992). The purpose of this report is to calculate potential maximum radiation dose rates for both present and possible future use conditions on the basis of postremediation concentration levels. The RESRAD computer code, which implements the methodology described in DOE's manual for implementing residual radioactive material guidelines (Gilbert et al. 1989), was used to perform a dose assessment for the Elza Gate site.

\subsection{SITE DESCRIPTION AND SETTING}

The Elza Gate site covers about 8 ha (20 acres) in the southeastern part of the city of Oak Ridge, Tennessee, near the intersection of Melton Lake Drive and Oak Ridge Turnpike (Figure 1). Access to the site is unrestricted. The site became contaminated with radioactive materials when the Manhattan Engineer District (MED) and, subsequently, the U.S. Atomic Energy Commission (AEC) stored uranium ore and ore-processing residues there between 1940 and 1972. Polychlorinated biphenyls (PCBs) found on the site resulted from the storage of electrical equipment by DOE predecessor agencies. The site, also known as the Melton Lake Industrial Park, is owned by MECO, a real estate development company. Currently, the site is not being used; however, MECO is developing it for future use as an industrial park.

The regional topography is characterized by a series of northeast-southwest trending ridges and intervening valleys. The ridges are breached at irregular intervals by stream channels that otherwise follow the trend of the valleys. Ridges in the area reach elevations of approximately $300 \mathrm{~m}(1,000 \mathrm{ft})$ above mean sea level (MSL). The elevation of the Elza Gate site is approximately $250 \mathrm{~m}(820 \mathrm{ft})$ above MSL; it is about $150 \mathrm{~m}(500 \mathrm{ft})$ from the western shore of a tributary of the Clinch River (Figure 1). The Clinch River, which eventually discharges into the Tennessee River, is the source of most of the water used in the Oak Ridge area. The Melton Hill Reservoir lies south of the site (Figure 2). The site lies outside the 100-year floodplain (Poligone 1990). Soils in the site area are sandy loams.

The climate at Oak Ridge is warm and humid. Summers are dominated by warm, moist air from the Gulf of Mexico. In the winter, cold, dry air masses from Canada are warmed as the air crosses the Cumberland Mountains and moves down the eastern slopes to the Oak Ridge area. Precipitation averages $140 \mathrm{~cm}$ (55 in.) annually; the relative humidity averages $70 \%$. The maximum 24-hour rainfall is about $20 \mathrm{~cm}$ (8 in.). Approximately $70 \%$ of the average annual precipitation is lost through evapotranspiration; the rest becomes runoff to surface waters and recharge to the groundwater. Snow is infrequent but sometimes falls in sufficient quantity to hinder traffic and outdoor activities. Winds on the ridges blow predominantly from the southwest, although winds from the northeast are also frequent. Remnants of hurricanes and tropical storms occasionally affect the area. 


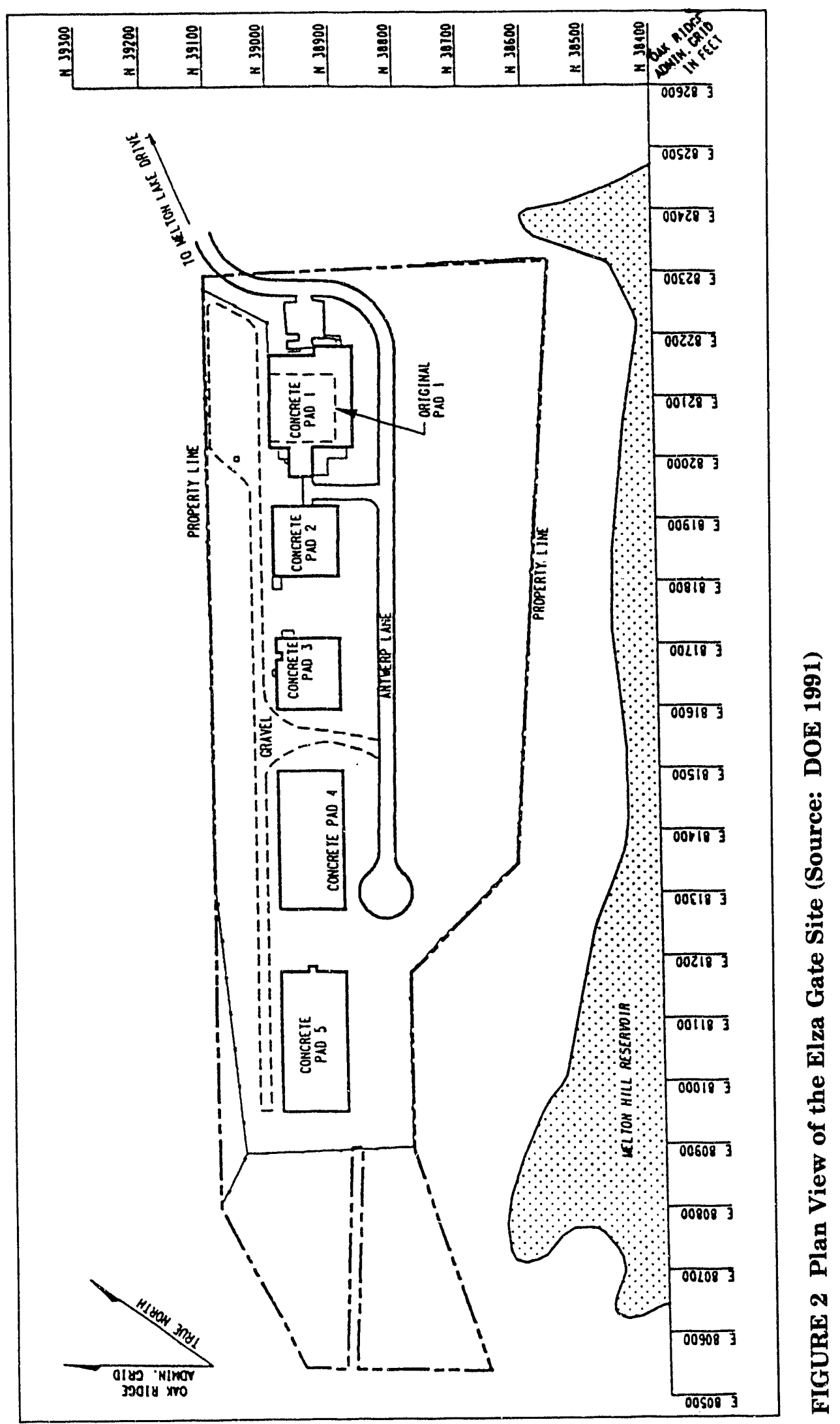




\subsection{SITE HISTORY}

During the 1940s, the MED stored pitchblende (a high-grade uranium ore from Africa), residue from ore processing, and other radioactive material at the Elza Gate site. Originally, the site housed five warehouses, at least three of which stored radioactive material. In 1946, ownership of the site passed to the AEC, which used the warehouses for storage until they were vacated in 1972. During the MED/AEC era, the complex was accessed by a railroad spur to the southeast and by a road that entered from what is now Melton Lake Drive. The railroad spur has since been removed.

After a radiological survey and decontamination by Oak Ridge National Laboratory (ORNL) in 1972, it was recommended that the site be released for use without radiological restrictions (Sapirie 1972). The original warehouse buildings were removed; however, the concrete pads were left in place (Figure 2). The property was then relinquished by the AEC in 1972 , and the city of Oak Ridge assumed title to the property. That same year, the city sold the property to Jet Air, Inc., which operated a fabricating and metal plating facility on the site. Jet Air, in turn, sold the property to MECO in 1988.

In 1987, at the request of the Tennessee Department of Health and Environment, Oak Ridge Associated Universities (ORAU) conducted a survey at the site because of the possibility of contamination from the Jet Air metal plating facility (Egli 1988). The survey confirmed the presence of heavy metal contamination. In addition, uranium was discovered in the soil at concentrations above background levels.

In 1988, MECO added offices to the structure on Pad 1 built by Jet Air and constructed a new access road to develop the property for lease and sale as an industrial park (Figure 2). In October and November 1988, the pad area along Antwerp Lane was radiologically surveyed by the Measurement Applications and Development Group of ORNL (Cottrell et al. 1989). This area and the original site access road were found to exceed DOE's radiological criteria for unrestricted use of a site, making the site eligible for inclusion in FUSRAP. On November 30, 1988, the entire Melton Lake Industrial Park was authorized for inclusion in FUSPAP (Fiore 1988).

In 1989 and 1990, comprehensive radiological, chemical, and hydrogeological characterization activities were conducted at the Elza Gate site to determine the boundaries of contamination that exceed DOE guidelines. In general, these surveys indicated levels of radioactive contamination exceeding DOE guidelines around the edges of the concrete pads, in the cul-de-sac of the access road, and in several other small areas on the site (BNI 1991). Remedial action was conducted at the site in 1991 and 1992 on the basis of these characterization data. 


\subsection{SUMMARY OF REMEDIAL ACTION ACTIVITIES}

The DOE remedial action guidelines for alpha activity on concrete surfaces are $5,000 \mathrm{dpm} / 100 \mathrm{~cm}^{2}$ average, $15,000 \mathrm{dpm} / 100 \mathrm{~cm}^{2}$ maximum, and $1,000 \mathrm{dpm} / 100 \mathrm{~cm}^{2}$ removable (DOE 1990). The DOE guidelines for radium-226, thorium-232, and thorium-230 concentrations in soil are $5 \mathrm{pCi} / \mathrm{g}$ when averaged over the first $15 \mathrm{~cm}(6 \mathrm{in}$.) of soil below the surface and $15 \mathrm{pCi} / \mathrm{g}$ when averaged over any soil layer $15 \mathrm{~cm}(6 \mathrm{in}$.) thick below the surface layer, excluding background concentrations (DOE 1990, 1992). For uranium-238, a sitespecific guideline of $35 \mathrm{pCi} / \mathrm{g}$ was derived (Wagoner 1991). Where contamination exceeded applicable guidelines, remedial action was conducted until measurements indicated that DOE guidelines had been met.

Remedial action at the Elza Gate site was conducted in two phases. Details of the remedial action sampling are provided by BNI (1992). The estimated dose to the remedial action workers is given by DOE (1991). Phase I consisted of removing the original concrete Pad 1, excavating contaminated soil beneath the pad, and excavating soil from five other areas outside the building (Figure 3). The soil beneath Pad 1 was removed to a depth of approximately $0.5 \mathrm{~m}(1.5 \mathrm{ft})$. The five remediated areas outside the industrial building were excavated to the depths indicated in Figure 3. In 1992, a new concrete pad was laid in the area of the preexisting concrete Pad 1 (Keller 1993). A total of $373 \mathrm{~m}^{3}\left(488 \mathrm{yd}^{3}\right)$ of contaminated soil was removed from beneath $\operatorname{Pad} 1 ; 112 \mathrm{~m}^{3}\left(146 \mathrm{yd}^{3}\right)$ was removed from the five areas outside the building (BNI 1992). Phase II of the remedial action consisted of completely removing concrete Pads 2, 3, and 4 (including their associated foundations), removing a small section of Pad 5, and excavating contaminated soil from beneath the pads and at other locations across the site (Duffy 1991). Figure 4 shows the areas of radioactive contamination remediated during Phase II. The maximum depth of radioactive contamination was $2.1 \mathrm{~m}(7 \mathrm{ft})$.

All contaminated concrete and soil removed during both phases of remedial action was transported to the DOE Oak Ridge Reservation and used as fill material in the closure of the United Nuclear Corporation disposal site. Approximately $5,124 \mathrm{~m}^{3}\left(6,700 \mathrm{yd}^{3}\right)$ of material was taken to the disposal site (Wagoner 1991). The structures that currently exist at the site include the building, the concrete pad laid on the perimeter of the original concrete $\mathrm{Pad} 1$, the new concrete pad laid in the area of the preexisting concrete Pad 1, concrete Pad 5, and Antwerp Lane Road (Keller 1993).

Radiological surveys were conducted as remedial actions were completed to confirm that no radioactivity exceeding DOE guidelines remained in the remediated areas. These surveys included direct surface measurements on the concrete pads and analysis of soil samples collected from excavated areas. Survey results indicated that the areas identified as exceeding guidelines during characterization activities were successfully brought into compliance with applicable DOE cleanup guidelines for radioactive contamination (BNI 1992; Vitkus and Bright 1992). Compliance with U.S. Environmental Protection Agency guidelines for chemical contamination was also achieved during cleanup of areas contaminated with lead and PCBs (BNI 1992; Vitkus and Bright 1992). 


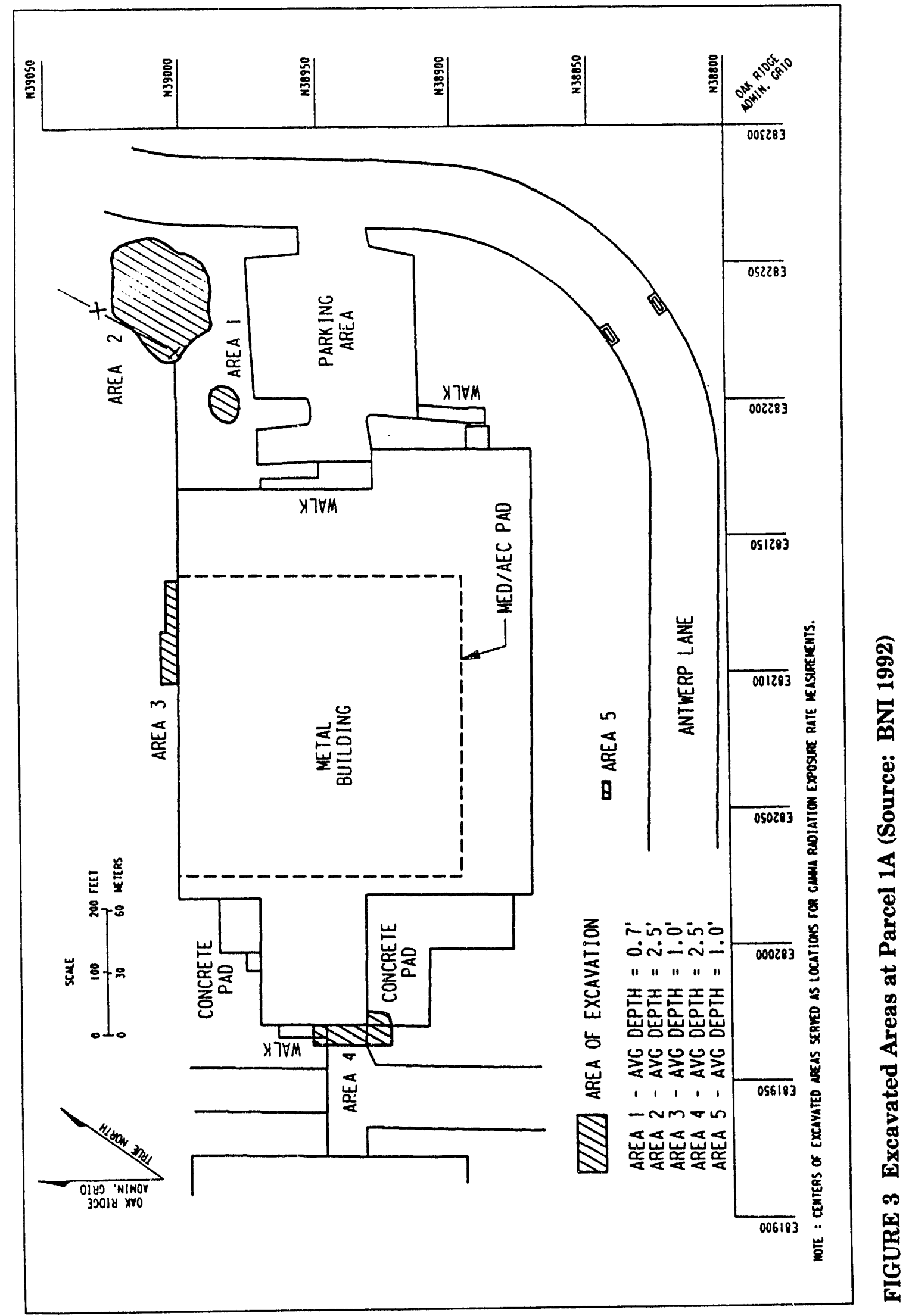




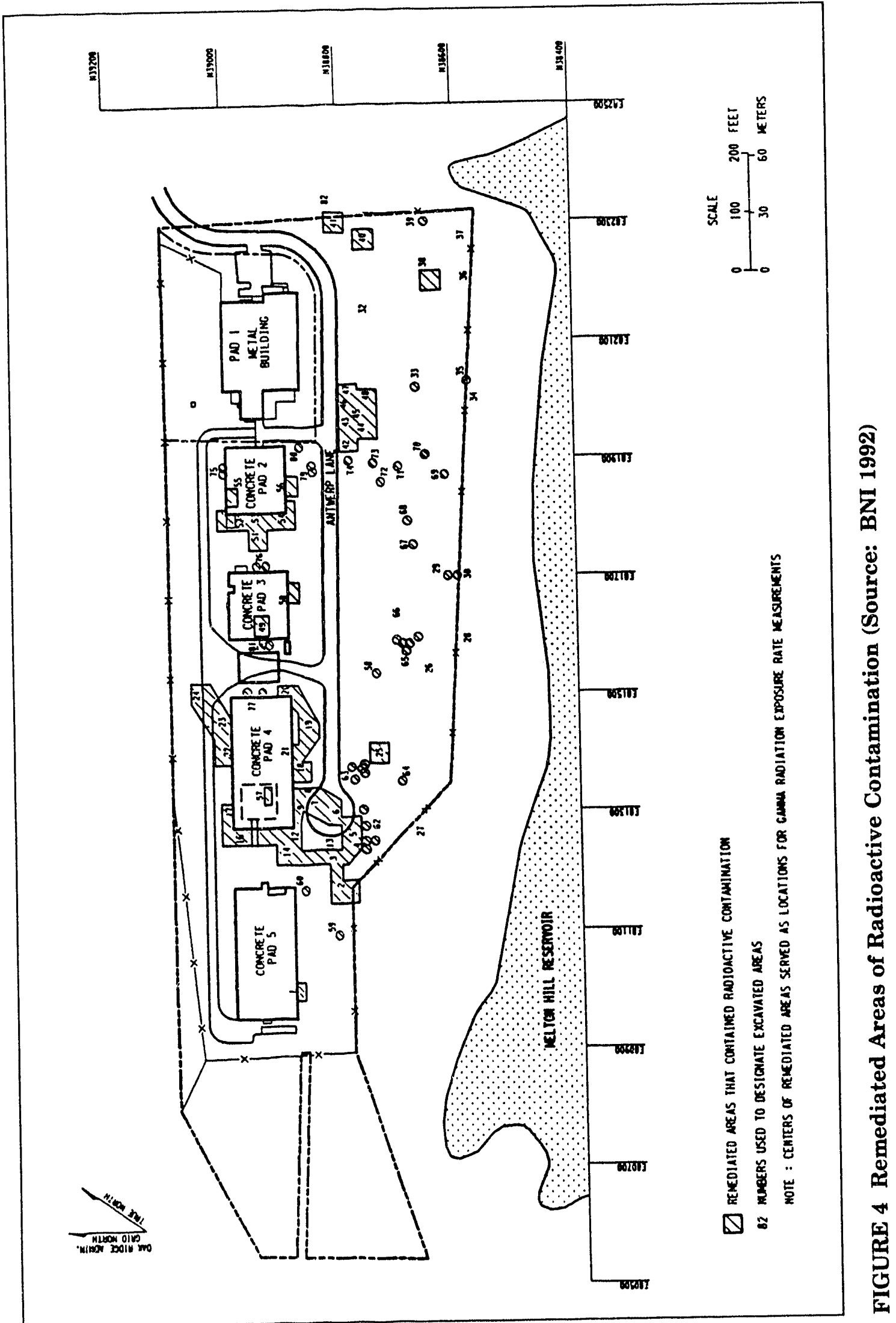




\section{SCENARIO DEFINITIONS}

Currently, the Elza Gate site is not being used; however, for assessing postremediation dose, four potential exposure scenarios were considered. All scenarios assumed that at some time within 1,000 years the Elza Gate site will be released for use without radiological restrictions. Potential radiation doses resulting from nine exposure pathways were analyzed: (1) direct exposure to external radiation from the decontaminated soil material, (2) internal radiation from inhalation of contaminated dust, (3) internal radiation from inhalation of emanating radon-222, (4) internal radiation from ingestion of on-site soil, (5) internal radiation from ingestion of plant foods grown in the decontaminated area and irrigated with water drawn from the pond or well adjacent to the decontaminated area on the downgradient side, (6) internal radiation from ingestion of meat from livestock fed with fodder grown in the decontaminated area and water drawn from the pond or well, (7) internal radiation from ingestion of milk from livestock fed with fodder grown in the decontaminated area and water drawn from the pond or well, (8) internal radiation from ingestion of aquatic food (fish) from the pond, and (9) internal radiation from drinking water drawn from the pond or well.

Scenario A (the expected scenario) assumes industrial use of the site. A hypothetical person is assumed to work in the area of the site for 8 hours per day (6 hours outdoors and 2 hours indoors), 5 days per week, 50 weeks per year. The industrial worker does not ingest drinking water, plant foods, or fish from the remediated area; neither does the worker ingest meat or milk from livestock raised in the remediated area.

Scenario B (a plausible scenario) assumes recreational use of the site. It is assumed that, at some time in the future, the site will be used as a public park. A hypothetical person spends 15 hours per week, 50 weeks per year in the decontaminated area of the park. The recreationist does not ingest drinking water, plant foods, or fish from the decontaminated area or ingest meat or milk from livestock raised in the decontaminated area.

Scenario C (a possible but unlikely scenario) assumes the presence of a resident farmer in the immediate vicinity of the site who drinks water obtained from a pond adjacent to and downstream of the decontaminated area, ingests plant foods grown in a garden in the decontaminated area, and ingests meat and milk from livestock raised in the decontaminated area. All water used by the farmer is drawn from the pond adjacent to the decontaminated area. The individual also ingests fish taken from the pond.

As in Scenario C, Scenario D (a possible but unlikely scenario) assumes the presence of a resident farmer; however, in this scinario, groundwater drawn from a well located at the downgradient edge of the contaminated zone is the only water source for drinking, irrigation, and raising livestock.

The RESRAD computer code (Gilbert et al. 1989) was used to calculate the radiation doses for the hypothetical future worker, recreationist, or resident for the four scenarios, on the basis of the following assumptions. 
- Scenario A

- The industrial worker spends 2,000 hours per year on-site (25\% indoors and $\mathbf{7 5 \%}$ outdoors).

- The worker does not consume any meat, milk, water, aquatic food, or vegetables from the site.

- The walls, floor, and foundation of the industrial building reduce external exposure by $30 \%$; the indoor dust level is $40 \%$ of the outdoor dust level (Gilbert et al. 1989).

- The depth of the house or building foundation is $1 \mathrm{~m}(3 \mathrm{ft})$ below the ground surface, with an effective radon diffusion coefficient of $2 \times 10^{-6} \mathrm{~m}^{2} / \mathrm{s}$.

- Scenario B

- The recreationist spends 750 hours per year on-site, all outdoors.

- The recreationist does not consume any meat, milk, water, aquatic food, or vegetables from the site.

- Scenario C

- The resident farmer spends $50 \%$ of the time indoors in the remediated area, $25 \%$ outdoors in the repsediated area, and $25 \%$ away from the remediated area.

- The decontaminated area is large enough that 50\% of the plant food diet consumed by the resident farmer is grown in a garden in the decontaminated area.

- The decontaminated area is large enough to provide sufficient meat and milk for the resident farmer from livestock raised (i.e., foraged) in the remediated area.

- Vegetables are irrigated by and livestock are provided with water drawn from the pond located adjacent to the decontaminated area.

- The adjacent pond provides $50 \%$ of the aquatic food consumed by the resident farmer.

- The adjacent pond provides $100 \%$ of the drinking water consumed by the resident farmer. 


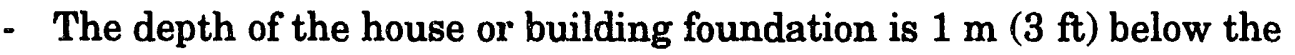
ground surface, with an effective radon diffusion coefficient of $2 \times 10^{-6} \mathrm{~m}^{2} / \mathrm{s}$.

- Scenario D

- All assumptions are the same as for Scenario C; however, groundwater drawn from a well at the downgradient edge of the contaminated zone is the only water source for drinking, irrigation, and raising livestock.

All pathways considered for Scenarios A, B, C, and D are summarized in Table 1.

TABLE 1 Summary of Pathways for Scenarios A, B, C, and D at the Elza Gate Site ${ }^{a}$

\begin{tabular}{lcccc}
\multicolumn{1}{c}{ Pathway } & Scenario A & Scenario B & Scenario C & Scenario D \\
\hline $\begin{array}{l}\text { External gamma exposure } \\
\begin{array}{l}\text { Inhalation } \\
\text { Dust }\end{array}\end{array}$ & Yes & Yes & Yes & Yes \\
$\begin{array}{l}\text { Radon } \\
\text { Ingestion }\end{array}$ & Yes & Yes & Yes & Yes \\
Plant foods & Yes & Yes & Yes & Yes \\
Meat & & & & Yes \\
Milk & No & No & Yes & Yes \\
Fish & No & No & Yes & Yes \\
Soil & No & No & Yes & Yes \\
Water & No & No & Yes & Yes \\
\hline
\end{tabular}

a Scenario A, industrial worker; Scenario B, recreationist; Scenarios C and D; resident farmer.

b Source of water used: $100 \%$ pond water for drinking, irrigation, and livestock for Scenario C; $100 \%$ well water for Scenario D. 


\section{SOURCE TERMS}

The source term concentrations used in the RESRAD computer code were calculated with data collected from a postremedial soil survey (BNI 1992). Approximately 150 soil samples were collected from areas excavated during Phases I and II of the remedial action. The survey included measured residual concentrations of uranium-238, radium-226, thorium-230, and thorium-232. The results of the soil samples indicate that radionuclide concentrations do not exceed the DOE remedial action guidelines (BNI 1992). Depths of residual contamination ranged from 0 to $3.4 \mathrm{~m}$ ( 0 to $11 \mathrm{ft}$ ), but residual contamination was typically confined to the top $1.5 \mathrm{~m}(5 \mathrm{ft})$ of soil. Average background concentrations were also reported in the postremedial soil survey report (BNI 1992). The average concentrations are based on soil soncentrations taken from three background locations within an 8-km (5-mi) radius of the site.

All scenarios assumed that the construction of a house or industrial building would result in excavation and mixing of on-site soil. Because of the excavation and mixing of soil, radionuclide concentrations for the entire site were based on the arithmetic average of soil data given in Tables 4-1 and 4-2 of the postremedial survey report (BNI 1992). The average radionuclide concentrations for uranium-238 and thorium-230 for the entire site were used in this assessment (background concentrations were subtracted). The average radium-226 and thorium-232 concentrations were comparable to background levels; therefore, they were not considered in this analysis (Table 2). Concentrations of uranium-234 and uranium-235 were inferred on the basis of the assumption that uranium-238, uranium-234, and uranium-235 are present in their natural activity concentration ratio of 1:1:0.046. In addition, the concentrations of actinium-227 and protactinium-231 were assumed to be in secular equilibrium with uranium-235. The radionuclide concentrations used in the RESRAD computer code are presented in Table 2. The various parameters used in the RESRAD code are listed in the Appendix. Except for the radionuclide concentrations and the area of contamination, all values used in the RESRAD computer code were those used in deriving the uranium guidelines for the site (Cheng et al. 1991). 
TABLE 2 Radionuclide Concentrations (pCi/g) Used in the RESRAD Code for Analysis of the Elza Gate Site

\begin{tabular}{lccc}
\hline Radionuclide & $\begin{array}{c}\text { Average } \\
\text { Radionuclide } \\
\text { Concentration }^{\mathrm{a}}\end{array}$ & $\begin{array}{c}\text { Average } \\
\text { Background } \\
\text { Radionuclide } \\
\text { Concentration }^{\mathrm{b}}\end{array}$ & $\begin{array}{c}\text { Radionuclide } \\
\text { Concentration Used } \\
\text { in RESRAD }\end{array}$ \\
\hline Uranium-238 & 5.9 & 1.0 & 4.9 \\
Radium-226 & 1.0 & 1.3 & $\mathrm{NA}^{\mathrm{d}}$ \\
Thorium-232 & 1.3 & 1.5 & $\mathrm{NA}^{\mathrm{A}}$ \\
Thorium-230 & 2.5 & 1.0 & 1.5 \\
Uranium-234 & $-\mathrm{e}$ & - & $4.9^{\mathrm{f}}$ \\
Uranium-235 & - & - & $0.22^{\mathrm{f}}$ \\
Actinium-227 & - & - & $0.22^{\mathrm{g}}$ \\
Protactinium-231 & - & - & $0.22^{\mathrm{g}}$ \\
\hline
\end{tabular}

a Average radionuclide concentrations were calculated on the basis of soil data given in Tables 4-1 and 4-2 of BNI (1992).

b Source: BNI (1992).

c The background radionuclide concentration is subtracted from the average radionuclide concentration.

d $\mathrm{NA}=$ not applicable because the concentration is below background.

e A hyphen indicates that the concentration was not measured for this radionuclide.

f Concentration based on the assumption that uranium-238, uranium-234, and uranium-235 are present in their natural activity concentration ratio of $1: 1: 0.046$.

g Concentration based on the assumption that the radionuclide is in secular equilibrium with uranium-235. 


\section{RESULTS}

The RESRAD computer code was used to calculate the potential radiation doses for each exposure scenario. The time frame considered in this analysis was 1,000 years. Radioactive decay and ingrowth were considered in calculating the maximum dose rates. The various parameters used in the RESRAD code for this analysis are listed in the Appendix. The calculated maximum dose rates for Scenarios A, B, C, and D ire presented in Table 3.

For all scenarios, the maximum dose rate does not exceed the DOE annual limit of $100 \mathrm{mrem} / \mathrm{yr}$ (DOE 1990, 1992). For Scenarios A (industrial worker) and B (recreationist), the maximum dose occurs at time 0 (the year the postremediation radiological survey was conducted). The times at which the maximum dose rate would occur are 729 and 792 years following the postremediation radiological survey for Scenarios $\mathbf{C}$ and D (resident farmers), respectively. The maximum dose rates for Scenarios A (industrial worker) and B (recreationist) are less than $2 \mathrm{mrem} / \mathrm{yr}$. For these two scenarios, inhalation of dust is the dominant pathway, contributing approximately $73 \%$ of the total annual dose. For Scenarios C (resident farmer: 100\% pond water) and D (resident farmer: 100\%

TABLE 3 Summary of Potential Maximum Dose Rates (mrem/yr) for Scenarios A, B, C, and D at the Elza Gate Site ${ }^{\mathrm{a}}$

\begin{tabular}{lcccc}
\hline \multicolumn{1}{c}{ Pathway } & Scenario A & Scenario B & Scenario C & Scenario D \\
\hline $\begin{array}{l}\text { External gamma exposure } \\
\text { Inhalation }\end{array}$ & 0.31 & 0.13 & 1.9 & 1.8 \\
$\quad$ Dust & 1.1 & 0.50 & 0.78 & 0.72 \\
$\quad$ Radon & 0 & 0 & 0.66 & 0.66 \\
Ingestion & & & & \\
Plant foods & NA & NA & 7.2 & 11 \\
Meat & NA & NA & 0.51 & 3.8 \\
Milk & NA & NA & 0.014 & 0.24 \\
Fish & NA & NA & 0.24 & 0.25 \\
Soil & 0.064 & 0.028 & 0.059 & 0.056 \\
Water & NA & NA & 0.31 & 23 \\
Total & 1.5 & 0.66 & 12 & 42 \\
\hline
\end{tabular}

a For Scenarios A and B, the maximum dose occurs at time 0 (the year the postremediation radiological survey was conducted). The times at which the maximum dose rate would occur are 729 and 792 years following the postremediation radiological survey for Scenarios $C$ and $D$, respectively.

b $\mathrm{NA}=$ not applicable because it is not a pathway of concern.

c Source of water used: $100 \%$ pond water for drinking, irrigation, and livestock for Scenario C; $100 \%$ well water for Scenario D. 
groundwater), the maximum dose rates are 12 and $42 \mathrm{mrem} / \mathrm{yr}$, respectively. The plant ingestion pathway contributes approximately $60 \%$ of the dose, and the external gamma irradiation contributes approximately $16 \%$ of the total annual dose for Scenario C. For Scenario D, the plant ingestion pathway contributes approximately $26 \%$ of the total annual dose, while the external gamma irradiation and the ingestion of meat contribute approximately 4 and 9\%, respectively, of the dose. Ingestion of groundwater for Scenario D (resident farmer: $100 \%$ groundwater) accounts for about 55\% of the total annual dose, whereas ingestion of water from the pond (Scenario C) contributes only $3 \%$ of the total annual dose. 


\section{REFERENCES}

BNI (Bechtel National, Inc.), 1991, Characterization Report for the Elza Gate Site, Oak Ridge, Tennessee, prepared for U.S. Department of Energy, Oak Ridge Operations Office, Oak Ridge, Tenn.

BNI, 1992, Post-Remedial Action Report for the Elza Gate Site, DOE/OR/21949-352, prepared for U.S. Department of Energy, Oak Ridge Operations Office, Oak Ridge, Tenn., Oct.

Cheng, J.-J., et al., 1991, Derivation of Uranium Residual Radioactive Material Guidelines for the Elza Gate Site, prepared by Argonne National Laboratory, Argonne, Ill., for U.S. Department of Energy, Oak Ridge Operations Office, Oak Ridge, Tenn.

Cottrell, W.D., et al., 1989, Preliminary Site Survey Report for the Former Elza Gate Warehouse Area, Oak Ridge, Tennessee, ORNL/RASA-89/4, Oak Ridge National Laboratory, Oak Ridge, Tenn.

Duffy, L.P., 1991, Categorical Exclusion Determination - Removal Action at Elza Gate, Tennessee, memorandum from Duffy (Director, Office of Environmental Restoration and Waste Management, U.S. Department of Energy) to C.M. Borgstrom (Director, Office of National Environmental Policy Act Oversight, U.S. Department of Energy), Aug. 26.

Egli, R.L., 1988, Sampling Data for Land Parcel 228, letter from Egli (U.S. Department of Energy, Oak Ridge Operations, Former Sites Restoration Division, Oak Ridge, Tenn.) to K. Cole (Oak Ridge, Tenn.), April 25.

Fiore, J.J., 1988, Authorization for Remedial Action at the Melton Lake Industrial Park (Former Elza Gate Area Warehouses), Oak Ridge, Tennessee, memorandum from Fiore (Director, Division of Facility and Site Decommissioning Projects, Office of Nuclear Energy, U.S. Department of Energy, Washington, D.C.) to P. Gross (U.S. Department of Energy, Oak Ridge Operations, Technical Services Division, Oak Ridge, Tenn.), Nov. 30.

Gilbert, T.L., et al., 1989, A Manual for Implementing Residual Radioactive Material Guidelines, ANL/ES-160, DOE/CH/8901, prepared by Argonne National Laboratory, Argonne, Ill., for U.S. Department of Energy, Assistant Secretary for Nuclear Energy, Washington, D.C.

Keller, M., 1993, telephone call from Keller (Bechtel National, Inc., Oak Ridge, Tenn.) to M. Nimmagadda (Argonne National Laboratory, Argonne, Ill.), Feb. 16.

Poligone, M., 1990, letter from Poligone (Bechtel National, Inc., Oak Ridge, Tenn.) to J.S. Devgun (Argonne National Laboratory, Argonne, Ill.), Oct. 9. 
Sapirie, S.R., 1972, Disposal of Excess Real Property - Parcel 228, letter from Sapirie to J.L. Smith (Attachment: Authorization for Remedial Action at the Melton Lake Industrial Park [former Elza Gate Area Warehouses]), Bechtel National, Inc., BNI CCN 057470, Oak Ridge, Tenn., Feb. 3.

DOE (U.S. Department of Energy), 1990, Radiation Protection of the Public and Environment, DOE Order 5400.5, Feb.

DOE, 1991, Engineering Evaluation / Cost Analysis for the Proposed Removal of Contaminated Materials at the Elza Gate Site, Oak Ridge, Tennessee, DOE/OR23701.3, Washington, D.C.

DOE, 1992, Radiological Control Manual, Assistant Secretary for Environment, Safety and Health, Washington, D.C., June.

Vitkus, T.J., and T.L. Bright, 1992, Verification Survey of the Elza Gate Site, Oak Ridge, Tennessee, ORISE 92/L-30, prepared by Oak Ridge Institute for Science and Education, Oak Ridge, Tenn., for U.S. Department of Energy, Dec.

Wagoner, J.W., 1991, Uranium Cleanup Guideline for the Elza Gate, Tennessee FUSRAP Site, letter from Wagoner (U.S. Department of Energy Headquarters, Washington, D.C.) to L.K. Price (Oak Ridge Field Office), BNI CCN 075376, Oak Ridge, Tenn., Feb. 6. 


\section{APPENDIX:}

\section{PARAMETERS USED IN THE ANALYSIS OF THE ELZA GATE SITE}

The parametric values used in the RESRAD code for the analysis of the Elza Gate Site are listed in Table A.1. All parametric values are reported to three significant figures. Sorru parametric values are specific to the Elza Gate Site; other values are generic.

\section{TABLE A.1 Parameters Used in the RESRAD Code for Analysis of the Elza Gate Site}

\begin{tabular}{|c|c|c|c|c|c|}
\hline \multirow[b]{2}{*}{ Parameter } & \multirow[b]{2}{*}{ Unit } & \multicolumn{4}{|c|}{ Value } \\
\hline & & Scenario A & Scenario B & Scenario C & Scenario D \\
\hline Area of contaminated zone $\mathrm{e}^{\mathrm{a}}$ & $\mathrm{m}^{2}$ & 80,930 & 80,930 & 80,930 & 80,930 \\
\hline Thickness of contaminated zone & $\mathbf{m}$ & 1.5 & 1.5 & 1.5 & 1.5 \\
\hline Length parallel to aquifer flow ${ }^{a}$ & $\mathbf{m}$ & 284 & 284 & 284 & 284 \\
\hline \multicolumn{6}{|l|}{ Initial principal radionuclide concentration } \\
\hline Actinium-227 & $\mathrm{pCi} / \mathrm{g}$ & 0.22 & 0.22 & 0.22 & 0.22 \\
\hline Protactinium-231 & $\mathrm{pCi} / \mathrm{g}$ & 0.22 & 0.22 & 0.22 & 0.22 \\
\hline Thorium-230 & $\mathrm{pCi} / \mathrm{g}$ & 1.5 & 1.5 & 1.5 & 1.5 \\
\hline Uranium-234 & $\mathrm{pCi} / \mathrm{g}$ & 4.9 & 4.9 & 4.9 & 4.9 \\
\hline Uranium-235 & $\mathrm{pCi} / \mathrm{g}$ & 0.22 & 0.22 & 0.22 & 0.22 \\
\hline Uranium-238 & $\mathrm{pCi} / \mathrm{g}$ & 4.9 & 4.9 & 4.9 & 4.9 \\
\hline Cover depth & m & 0 & 0 & 0 & 0 \\
\hline Density of contaminated zone & $\mathrm{g} / \mathrm{cm}^{3}$ & 1.8 & 1.8 & 1.8 & 1.8 \\
\hline Contaminated zone erosion rate & $\mathrm{m} / \mathrm{yr}$ & 0.0004 & 0.0004 & 0.0004 & 0.0004 \\
\hline Contaminated zone total porosity & $b$ & 0.4 & 0.4 & 0.4 & 0.4 \\
\hline Contaminated zone effective porosity &. $\mathrm{b}$ & 0.3 & 0.3 & 0.3 & 0.3 \\
\hline Contaminated zone hydraulic conductivity & $\mathrm{m} / \mathrm{yr}$ & 18.7 & 18.7 & 18.7 & 18.7 \\
\hline Contaminated zone b parameter & b & 7.12 & 7.12 & 7.12 & 7.12 \\
\hline Evapotranspiration coefficient &.$b$ & 0.7 & 0.7 & 0.7 & 0.7 \\
\hline Precipitation & $\mathrm{m} / \mathrm{yr}$ & 1.4 & 1.4 & 1.4 & 1.4 \\
\hline Irrigation & $\mathrm{m} / \mathrm{yr}$ & 0.3 & 0.3 & 0.3 & 0.3 \\
\hline Irrigation mode & b & not used & not used & overhead & overhead \\
\hline Runoff coefficient & b & 0.3 & 0.3 & 0.3 & 0.3 \\
\hline Watershed area for nearby pond & $\mathrm{m}^{2}$ & not used & not used & $7,560,000$ & $7,560,000$ \\
\hline Density of saturated zone & $\mathrm{g} / \mathrm{cm}^{3}$ & 2.0 & 2.0 & 2.0 & 2.0 \\
\hline Saturated zone total porosity & 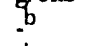 & not used & not used & 0.4 & 0.4 \\
\hline Saturated zone effective porosity &.$b$ & not used & not used & 0.3 & 0.3 \\
\hline Saturated zone hydraulic conductivity & $\mathrm{m} / \mathrm{yr}$ & not used & not used & 192 & 192 \\
\hline Saturated zone hydraulic gradient & $\mathrm{b}$ & not used & not used & 0.084 & 0.084 \\
\hline Saturated zone b parameter & b & 7.75 & 7.75 & 7.75 & 7.75 \\
\hline Water table drop rate & $\mathrm{m} / \mathrm{yr}$ & not used & not used & 0.0004 & 0.0004 \\
\hline Well pump intake depth (below water table) ${ }^{c}$ & $\mathbf{m}$ & not used & not used & 10 & 10 \\
\hline Model: nondispersion (ND) or mass-balance (MB) & b & not used & not used & ND & ND \\
\hline Number of unsaturated zone strata & b & not used & not used & 2 & 2 \\
\hline Unsaturated zone 1 , thickness & m & not used & not used & 1.4 & 1.4 \\
\hline Unsaturated zone 1 , soil density & $\mathrm{g} / \mathrm{cm}^{3}$ & not used & not used & 1.8 & 1.8 \\
\hline Unsaturated zone 1 , total porosity & b & not used & not used & 0.4 & 0.4 \\
\hline Unsaturated zone 1 , effective porosity &.$b$ & not used & not used & 0.3 & 0.3 \\
\hline Unsaturated zone 1 , soil-specific b parameter & $\mathrm{b}$ & not used & not used & 7.12 & 7.12 \\
\hline Unsaturated zone 1 , hydraulic conductivity & $\mathrm{m} / \mathrm{yr}$ & not used & not used & 18.7 & 18.7 \\
\hline Unsaturated zone 2 , thickness & $\mathrm{m}$ & not used & not used & 1.7 & 1.7 \\
\hline Unsaturated zone 2, soil density & $\mathrm{g} / \mathrm{cm}^{3}$ & not used & not used & 2.0 & 2.0 \\
\hline Unsaturated zone 2 , total porosity & & not used & not used & 0.4 & 0.4 \\
\hline
\end{tabular}


TABLE A.1 (Cont.)

\begin{tabular}{|c|c|c|c|c|c|}
\hline \multirow[b]{2}{*}{ Parameter } & \multirow[b]{2}{*}{ Unit } & \multicolumn{4}{|c|}{ Value } \\
\hline & & Scenario A & Scenario B & Scenario C & Scenario D \\
\hline Unsaturated zone 2, effective porosity & $-b$ & not used & not used & 0.3 & 0.3 \\
\hline Unsaturated zone 2, soil-specific b parameter & $-b$ & not used & not used & 7.75 & 7.75 \\
\hline Unsaturated zone 2 , hydraulic conductivity & $\mathbf{m} / \mathbf{y r}$ & not used & not used & 192 & 192 \\
\hline \multicolumn{6}{|l|}{ Distribution coefficient } \\
\hline Contaminated zone & $\mathrm{cm}^{3} / \mathrm{g}$ & & & & \\
\hline Uranium-234 & & 114 & 114 & 114 & 114 \\
\hline Uranium-235 & & 114 & 114 & 114 & 114 \\
\hline Uranium-238 & & 114 & 114 & 114 & 114 \\
\hline Actinium-227 $7^{\mathrm{c}, \mathrm{d}}$ & & 20 & 20 & 20 & 20 \\
\hline Protactinium-231 $1^{c, d}$ & & 50 & 50 & 50 & 50 \\
\hline Lead- $210^{c, d}$ & & 100 & 100 & 100 & 100 \\
\hline Radium-226 $6^{c, d}$ & & 70 & 70 & 70 & 70 \\
\hline Thorium-230 & & 276 & 276 & 276 & 276 \\
\hline \multicolumn{6}{|l|}{ Unsaturated zone 1} \\
\hline Uranium-234 & & 114 & 114 & 114 & 114 \\
\hline Uranium-235 & & 114 & 114 & 114 & 114 \\
\hline Uranium-238 & & 114 & 114 & 114 & 114 \\
\hline Actinium-227 $7^{\mathrm{c}, \mathrm{d}}$ & & 20 & 20 & 20 & 20 \\
\hline Protactinium-231 $1^{c, d}$ & & 50 & 50 & 50 & 50 \\
\hline Lead-210 & & 100 & 100 & 100 & 100 \\
\hline Radium-226 $6^{c, d}$ & & 70 & 70 & 70 & 70 \\
\hline Thorium-230 & & 276 & 276 & 276 & 276 \\
\hline \multicolumn{6}{|l|}{ Unsaturated zone 2} \\
\hline Uranium-234 & & 6.8 & 6.8 & 6.8 & 6.8 \\
\hline Uranium-235 & & 6.8 & 6.8 & 6.8 & 6.8 \\
\hline Uranium-238 & & 6.8 & 6.8 & 6.8 & 6.8 \\
\hline Actinium-227 ${ }^{\mathrm{c}, \mathrm{d}}$ & & 20 & 20 & 20 & 20 \\
\hline Protactinium-231 $1^{\mathrm{c}, \mathrm{d}}$ & & 50 & 50 & 50 & 50 \\
\hline Lead-210 $10^{\mathrm{c}, \mathrm{d}}$ & & 100 & 100 & 100 & 100 \\
\hline Radium-226 $6^{c, d}$ & & 70 & 70 & 70 & 70 \\
\hline Thorium-230 & & 276 & 276 & 276 & 276 \\
\hline \multicolumn{6}{|l|}{ Saturated zone } \\
\hline Uranium-234 & & 6.8 & 6.8 & 6.8 & 6.8 \\
\hline Uranium-235 & & 6.8 & 6.8 & 6.8 & 6.8 \\
\hline Uranium-238 & & 6.8 & 6.8 & 6.8 & 6.8 \\
\hline Actinium-227 $7^{\mathrm{c} d}$ & & 20 & 20 & 20 & 20 \\
\hline Protactinium-231 $1^{\mathrm{c}, \mathrm{d}}$ & & 50 & 50 & 50 & 50 \\
\hline Lead-210 ${ }^{c, d}$ & & 100 & 100 & 100 & 100 \\
\hline Radium-226 $6^{\mathrm{c}, \mathrm{d}}$ & & 70 & 70 & 70 & 70 \\
\hline Thorium-230 & & 276 & 276 & 276 & 276 \\
\hline Inhalation rate c $^{c}$ & $\mathrm{~m}^{3} / \mathrm{yr}$ & 8,400 & 8,400 & 8,400 & 8,400 \\
\hline Mass loading for inhalation ${ }^{c}$ & $\mathrm{~g} / \mathrm{m}^{2}$ & 0.0002 & 0.0002 & 0.0002 & 0.0002 \\
\hline Shielding factor, inhalation & - & 0.40 & 0.40 & 0.40 & 0.40 \\
\hline Shielding factor, external gamma & $-b$ & 0.70 & 0.70 & 0.70 & 0.70 \\
\hline Fraction of time spent indoors & $\therefore$ & 0.057 & 0 & 0.50 & 0.50 \\
\hline Fraction of time spent outdoors (on-site) & $\therefore$ & 0.171 & 0.086 & 0.25 & 0.25 \\
\hline Shape factor, external gammac & b & 1 & 1 & 1 & 1 \\
\hline Dilution length for airborne dust, inhalation ${ }^{c}$ & $\mathbf{m}$ & 3 & 3 & 3 & 3 \\
\hline Fruit, vegetable, and grain consumption ${ }^{\mathrm{c}}$ & $\mathrm{kg} / \mathrm{yr}$ & not used & not used & 160 & 160 \\
\hline Leafy vegetable consumption ${ }^{c}$ & $\mathrm{~kg} / \mathrm{yr}$ & not used & not used & 14 & 14 \\
\hline Milk consumption ${ }^{c}$ & L/yr & not used & not used & 92 & 92 \\
\hline Meat and poultry consumption ${ }^{c}$ & $\mathrm{~kg} / \mathrm{yr}$ & not used & not used & 63 & 63 \\
\hline Fish consumption ${ }^{c}$ & $\mathrm{~kg} / \mathrm{yr}$ & not used & not used & 5.4 & 5.4 \\
\hline Other seafood consumption ${ }^{c}$ & $\mathrm{~kg} / \mathrm{yr}$ & not used & not used & 0.9 & 0.9 \\
\hline Soil ingestion rate ${ }^{c}$ & $\mathrm{~g} / \mathrm{yr}$ & 36.5 & 36.5 & 36.5 & 36.5 \\
\hline Drinking water intake $e^{c}$ & $\mathrm{~L} / \mathrm{yr}$ & not used & not used & 510 & 510 \\
\hline Fraction of drinking water from site ${ }^{a}$ & $\mathrm{~b}$ & not used & not used & 1 & 1 \\
\hline
\end{tabular}


TABLE A.1 (Cont.)

\begin{tabular}{|c|c|c|c|c|c|}
\hline \multirow[b]{2}{*}{ Parameter } & \multirow[b]{2}{*}{ Unit } & \multicolumn{4}{|c|}{ Value } \\
\hline & & Scenario A & Scenario B & Scenario C & Scenario D \\
\hline Fraction of aquatic food from site ${ }^{a}$ & b & not used & not used & 0.5 & 0.5 \\
\hline Livestock fodder intake for meat ${ }^{\mathrm{c}}$ & $\mathrm{kg} / \mathrm{d}$ & not used & not used & 68 & 68 \\
\hline Livestock fodder intake for milk ${ }^{\mathrm{c}}$ & $\mathrm{kg} / \mathrm{d}$ & sot used & not used & 55 & 55 \\
\hline Livestock water intake for meat ${ }^{c}$ & $\mathrm{~L} / \mathrm{d}$ & not used & not used & 50 & 50 \\
\hline Livestock water intake for milk ${ }^{\mathrm{c}}$ & $L / d$ & not used & not used & 160 & 160 \\
\hline Mass loading for foliar deposition ${ }^{c}$ & $\mathrm{~g} / \mathrm{m}^{3}$ & not used & not $\cdot$ ised & 0.0001 & 0.0001 \\
\hline Depth of soil mixing layer ${ }^{c}$ & m & 0.15 & 0.15 & 0.15 & 0.15 \\
\hline Depth of roots $\mathbf{c}^{\mathrm{s}}$ & $\mathrm{m}$ & not used & not used & 0.9 & 0.9 \\
\hline $\begin{array}{l}\text { Groundwater fractional usage (balance } \\
\text { from surface water) }\end{array}$ & b & & & & \\
\hline Drinking water & & not used & not used & $\mathbf{0}$ & 1 \\
\hline Livestock water & & not used & not used & $\mathbf{0}$ & 1 \\
\hline Irrigation & & not used & not used & 0 & 1 \\
\hline Total porosity of the cover material ${ }^{\mathfrak{c}}$ & b & not used & not used & not used & not used \\
\hline $\begin{array}{l}\text { Total porosity of the house or } \\
\text { building foundation }\end{array}$ & b & 0.1 & not used & 0.1 & 0.1 \\
\hline Volumetric water content of the cover material ${ }^{c}$ & b & not used & not used & not used & not used \\
\hline Volumetric water content of the foundation ${ }^{c}$ & b & 0.05 & not used & 0.05 & 0.05 \\
\hline Diffusion coefficient for radon gas ${ }^{c}$ & $\mathbf{m} / \mathbf{s}$ & & & & \\
\hline In cover material & & $\begin{array}{l}\text { not used } \\
2.0 \times 10^{-8}\end{array}$ & $\begin{array}{l}\text { not used } \\
\text { not used }\end{array}$ & $\begin{array}{l}\text { not used } \\
2.0 \times 10^{-8}\end{array}$ & $\begin{array}{l}\text { not used } \\
2.0 \times 10^{-8}\end{array}$ \\
\hline $\begin{array}{l}\text { In foundation material } \\
\text { In contaminated zone soil }\end{array}$ & & $2.0 \times 10^{-6}$ & $\begin{array}{l}\text { not used } \\
2.0 \times 10^{-6}\end{array}$ & $2.0 \times 10^{-6}$ & $2.0 \times 10^{-6}$ \\
\hline Emanating power of radon gas $^{c}$ & b & 0.2 & 0.2 & 0.2 & 0.2 \\
\hline Radon vertical dimension of mixing ${ }^{c}$ & $\mathbf{m}$ & 2.0 & 2.0 & 2.0 & 2.0 \\
\hline Average annual wind speed ${ }^{c}$ & $\mathrm{~m} / \mathrm{s}$ & 2.0 & 2.0 & 2.0 & 2.0 \\
\hline Average building air exchange rate ${ }^{c}$ & $1 / \mathrm{h}$ & 1.0 & not used & 1.0 & 1.0 \\
\hline Height of the building (room) ${ }^{c}$ & $\mathbf{m}$ & 2.5 & not used & 2.5 & 2.5 \\
\hline Bulk density of house or building foundation ${ }^{c}$ & $\mathrm{~g} / \mathrm{cm}^{3}$ & 2.4 & not used & 2.4 & 2.4 \\
\hline Thickness of house or building foundation ${ }^{c}$ & m & 0.15 & not used & 0.15 & 0.15 \\
\hline Building depth below ground surface ${ }^{c}$ & $\overline{\mathrm{m}}$ & 1.0 & not used & 1.0 & 1.0 \\
\hline
\end{tabular}

a Values based on site specifications or scenario assumptions.

b Parameter is dimensionless.

c RESRAD default values.

d Radionuclide is a decay product.

Source: Liedle, S.D., 1990, letter from Liedle (Project Manager-FUSRAP, Bechtel National, Inc., Oak Ridge, Tenn.) to J.S. Devgun (Argonne National Laboratory, Argonne, Ill.), Sept. 20, except where indicated by footnotes "a" or "c." 

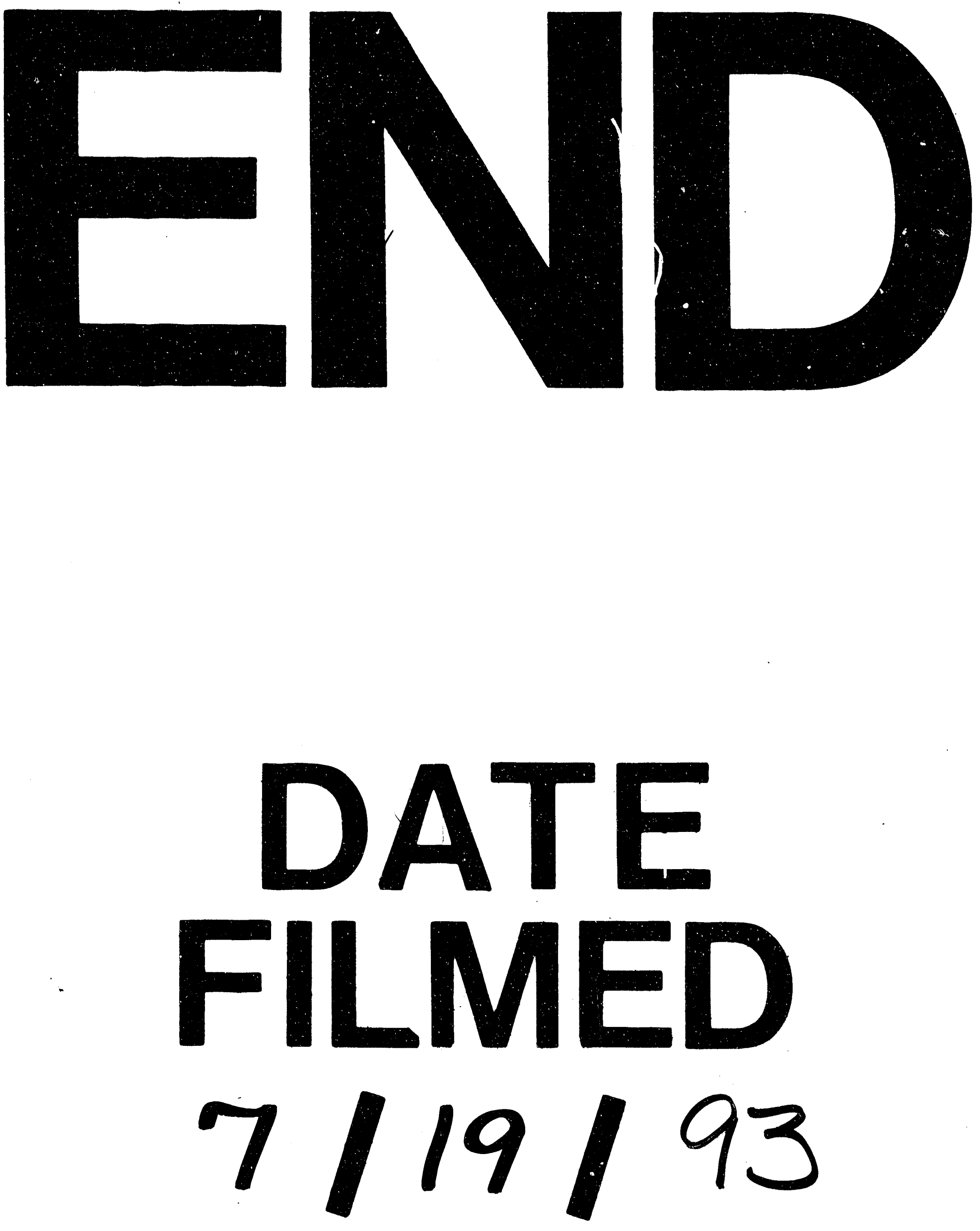

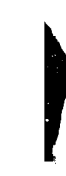


